\title{
Local Governance in Albania: The New Administrative-Territorial Reform
}

\author{
Aurora Ndreu MA LL.M PhD cand \\ Master Programme" South East European Law and European Integration" LL.M \\ Karl-Franzens University of Graz, Graz, Austria; Email: n.aurora@yahoo.com
}

\section{Doi:10.5901/ajis.2015.v4n3s1p515}

\begin{abstract}
Since the creation of the Albanian state, local government has seen numerous transformations influenced by various factors such as external and internal ones. This has led to a variety of bodies which have comparative basis between them for study purposes. Changes in the local governance organs have come as a result of adaptation to the way the country was governed. For research purposes, the work will be divided into four main parts, the part of the historical survey which covers the period 1920- 1944 and 1944-1990. During these periods occurred many changes in the content of local government in Albania. The third part deals with the local government after 1990, during the difficult period of transition and adaptation with the new legislation based on democratic principles and those of the European Union. The last part will be focused on the new administrative-territorial reform, as a very important experience that can bring fundamental changes in the organization of new local government bodies. In this research I will give a full overview of the definition of local government compared with other legislations mostly to the European Union member States. Then there will be a detailed study of historical and legal side of this local governance concept in our country, defining not only the elements but also its operation, ie organizational and functional side during the years 1920-1944 and 1945-1990. What were the main issues during the Zog period and foreign influence in local government organization. Practical achievement of such an organization and limitations. I will speak in detail on the Zog Law of Municipalities, one of the most successful laws that can compare with the current laws concerning the organization and functioning of local government. Later during the totalitarian system in Albania, which were the local government bodies, as they change, what functions and how were were composed. Then there will be treated the period post-90s, the period of transition, the organization of structures and issues in relation to adaptation and performance of their functions. Here it will be mentioned the changes that suffered the law on local government derived by EU law, which Albania was forced to implement as a result of the integration process. In the last part will be treated the new administrative-territorial reform, the way it was achieved this division, the methodology provided and reality in which the separation was made, the critical approach with regard to the constitutional aspect regarding the popular consultation and the values that this reform, positive and negative sides to it.
\end{abstract}

Keywords: Local governance, Municipalities, Albanian Law, Administrative-territorial reform, Communes.

\section{The Legal Base of Local Governance}

The first post-communist legal basis regarding the local governance was issued in 1992 which was not the best one since it was only a decision of the Council of Ministers about the country's administrative units. Our opinion on non representing the best of legal basis, derives from the fact that even during the communist dictatorship, such a very important decision for the country was approved by the Presidium of the National Assembly, giving not only a solemn importance to the issue but also a matter ligit which it was adopted. Thus the decision of Council of Ministers no.269 dated 25.06.1992 also set the administrative division in 357 units.

Following the above mentioned Decision of the Council of Ministers, there is a special law on local finances. Thus, in 1993 the Parliament passed the first law on December 22 called "The local budget". This law determined the annual financial program, incomes and expenses that each municipality has in the territory they operate.

For the first time we have an organic law on local governance only in 2000 which was preceded by the ratification by the Albanian state of the European Charter of Local Autonomy highlighting the lift to another level, in the political, economic and administrative level of the local government. Also this card has also provided the very important principle of subsidiarity, according to which the central government will exercise only those powers that can not be exercised by the local government. So from this principle emerges once again the division between central and local functions now also in the jurisdiction, which gave more impetus to local development. It already appears the term of decentralization meaning independence and disconnection of central and local government functions and powers.

Before this law was approved, it should be noted that was determined on the basis of constitutional level the 
organization and functioning of local government in the Albanian Constitution of 1998, which It gave a further importance and solemnity to these bodies.

Thus Article 108 of the Constitution of the Republic of Albania, stated that:

"The units of local government are communes or municipalities and regions."

According to the Constitution any other unit of local government shall be determined by a special law. Municipalities or communes were determined as the basic unit of local government, since they perform all the selfgoverning tasks and are in direct connection with the public and the citizens. As regard, municipalities and communes are first level units of local government and counties or regions are second level ones.

\section{Definition and the Subject of Local Governance}

The right of self-governance is guaranteed by Constitution to these organs. Article 108 states that this right is exercised through their representative bodies or by popular referendum.

The executive organs of local government units are the mayor of the municipality or that of commune, and as representative bodies are the municipal councils.

Given that Law No. 8652 dated 31.07.2000 "On the organization and functioning of local government" serves as the most important legal basis for our research, we will profoundly deal with. For the first time through this law it was determined who was part of the local government organization of its functioning, rights and duties of local government units.

The law stipulated that the local government units acts and exercise their functions and duties on the principle of local autonomy and that of subsidiarity. The basic unit of local governance were municipalities and communes.

Under the law aforementioned communes represents an administrative-territorial community of residents, mainly in rural areas but also in some cases in urban areas. While the municipality represents an administrative-territorial unity and community of residents usually in urban areas but in special cases even in rural areas. Municipalities were divided into neighborhoods and those were created by the decision of the City Council when crossing the 15,000 inhabitants.

The county or region was designated as the local government unit of the second level. It represented an administrative-territorial unity that consisted of communes and municipalities related between them through traditional, geographic, economic, social ties and bringing common interests.

It is interesting the fact that article 5 of the above law set the existence of the circle/ rreth, which is defined as subdivision of the county.

Law 8652 of 2000 was amended by Law 9208 dated 18.03.2004. Thus it was determined that the village was led by the leadership of the village which took the initiative on various issues of interest to the community and were proposed to municipal council for municipal review.

In 2001 the Council of Ministers approved the Decision No. 55 on the organization structure of the Civil Register offices, an integral part of local governments, whether in communes or municipalities. While in 2004, the Ministry of Territory adopted a guideline No. 4, dated 11.08.2004, which would serve to determine the manner of the exercise of powers by the local government regarding territory planning.

The legal basis was enriched with the decision of Council of Ministers No. 1619 dated 02.07 .2008 for classification of functions, grouping of local government units as for their payment and the setting of limits of salaries of local government bodies which were amended after with the decision No. 693 of 2010. Finally the organic law was amended by Law No. 30 of 2015, such changes were a result of the new administrative-territorial reform.

The legal basis has evolved and changed depending on the problems and cases of bodies of local government and relevant departments or the respective offices that emerged during their work. Also legal basis is divided on the legal basis of international acts, the legal basis of internal legal acts and legal basis to various acts adopted within the territory and jurisdiction of local authorities, given that the body of local government may issue regulations and make different decisions on which bases its work.

Local government is the people's right to govern their affairs within a given territory independently and through bodies which themselves choose within that territory directly. An independently governance is achieved on the basis of decentralization and local autonomy. Therefore, this principle takes priority in the existence of good practice in local government.

The functioning and organization of local governance depends on the legislation of the country and as provided in its constitution. Also the relationship with central government agencies depend on the constitutional meaning. 
Every part of the territory is administered by a government's municipal and all states within their territory recognizes and accept a set of values and principles on which local democracy functions. But the big problem of urban areas, it remains that how to structure and relate the different levels of organization meanwhile meeting the functional needs in the best manner possible.

We must distinguish between regional self-government and regional autonomy. The latter is a more powerful form, close to classical federalism than local self-government, which then brings a greater impact in the constitutional structure within the state.

In countries like Italy, Portugal, Spain or the United Kingdom we see a growing tendency that local authorities are developing where many of the public services are performed by the private sector.

Local autonomy is a term that includes steadily the academic and popular endless discussion about the local government, but rarely is defined carefully by a conceptual point of view or become the subject of an empirical research. Local autonomy can be defined as decentralization, as local fiscal discretion or as a "home-rule" adjustment to do or define rules within "your own house".

The central feature of local government in Albania is established and functions on the principle of local selfgovernment.

The objective of local government is to provide a governance as good as at the local level by being closer to citizens, recognizing and accepting the existence of values and different identities within different communities, through respect for the rights and freedoms of citizens. This objective is achieved through the effective exercise of the functions of local government itself or implementation of services through appropriate forms and above all promoting participation of community members in decision making.

The relationship between central and local government is based on the principle of subsidiarity and cooperation between them. To achieve a successful governance is needed this kind of cooperation in order to meet the best needs of the citizens.

\section{How the Local Government Units are Established}

These bodies are established under the law and as part of local government they are constitutional bodies.

The commune represents a group or community of residents who are resident in rural areas in general but are not excluded in any case the urban areas. It is an administrative-territorial unity. The name, residence or its territorial extension shall be determined by law. The commune is divided into smaller units which are villages but the law does not exclude that in special cases to be commune subdivisions even the cities.

The municipality consists of a group of citizens and communities that live in the city but do not exclude the case when includes rural areas. The name of the municipality and its territorial borders are defined by law. It is divided into areas and smaller territories called neighborhoods and the number of its population is determined by law. Neighborhoods can be created by a decision of the Municipal Council. In cases where the municipality includes rural areas as mentioned above, then this subdivision is called village. In any case, when there is create a new city, this is done by law and according to well-defined criteria regarding the prospects of urban development and the number of inhabitants or its urbanization.

The County ${ }^{1}$ or region is a second level unit, an administrative-territorial entity which included municipalities and communes which have geographic, territorial, economic, traditional and social ties and relationships. The region has a boundary that is determined by the boundary of those communes or municipalities that is composed from, and his name is defined by law. His center usually is one of the main municipalities that has under its territory. Currently there are twelve regions ${ }^{2}$ throughout the territory.

If mayors of municipalities or communes or municipal councilors are elected directly by the people by universal suffrage, the president of the Regional Council or its members are elected indirectly. So the members of it are the members of municipal councils or mayors depending on the population of the local government units.

As a region subdivision earlier was determined the circle/rreth ${ }^{3}$ but this is not any more defined as a term, after the latest changes on the law. This is not provided in the administrative division or organization of local governments.

\footnotetext{
1 The Albanian term for this is Qark

${ }^{2}$ These are: Lezhe, Durres, Berat, Diber, Kukes, Elbasan, Tirane, Fier, Korce, Gjirokaster, Shkoder, Vlore

${ }^{3}$ Law 8652, article 5, paragraph 6
} 


\section{The Representative Bodies of Local Government}

In Chapter VI of the organic law ${ }^{4}$ on local governance is defined the composition, creation, and organization, powers and duties of the municipal council.

The municipal pr commune council is the representative body of the municipality or commune and it consists of councilors elected by the people under the provisions of the Electoral Code of the Republic of Albania. The number of members of these councils depends on the number of population of the local government unit. According to the law on local governance, Article 24, the local government units that have up to five thousand people are represented by a council consisting of 13 members. The local units with number of population of five thousand to ten thousand, are represented by fifteen members, those with a population of ten thousand to twenty thousand are represented by seventeen members, those with a population of twenty thousand to fifty thousand are represented by twenty-five members and those with a population from fifty thousand to one hundred are represented by thirty-five members, those with a population from one hundred thousand to two hundred thousand are represented by forty-five members. The Municipality of Tirana, the municipality with the largest population in the country is represented by fifty-five members of the council. The prefect, as representative of the central government to local governments, depending on the number of people layed out of the Civil Register of the territory, of January 1 of the election year, determines the number of members than would be in the municipal council.

Members of the municipal council shall not be at the same time the mayor or deputy mayor of the municipality, then their function is incompatible and should therefore leave one of the functions. Also they can not be civil servants of local government units or secretaries of local municipal council or perform the function of a parliament member. It has to be underlined that the law excludes categorically that within the same local government council members have family or marriage ties, such as husbands, parents and children, siblings, or parents-in-law of the bride or groom. Elections for members of the councils of local governments are made at the same time as the elections for the mayor of the local government unit.

After the election, depending on the votes cast, each member receives a mandate from the election commission. Within twenty days from the announcement of election results by the Central Election Commission and the receiving of each mandate, is held the first meeting of the local government council. This meeting is called by the secretary of the local government council and when he does not call, then the mayor is the one who calls the first meeting of the council. The law provides for the fact that what happens if none of the above entities does not exercise its right to convene the first meeting of the council. According to Article 26, paragraph 3 of the organic law5, if no entity does not call a meeting for various reasons, then the council would be convened by his own initiative within ten days. This meeting is valid providing there participate more than half of its members, if the majority is not achieved, then the meeting is postponed for three days. This can be repeated up to three times, and if these three times a quorum is not reached to develop the meeting, then the council of the local unit is considered dispersed.

Until the election of president of the council of the local unit, the meeting is headed by the older member of the council. In the first meeting usually is elected the committee of mandates that will make the validitation of mandates, then every member will make the sworn and only at this time they start their duty as local councilors. The council is constituted only if it is made validation of the mandates of more than half of councilors. After that they have the right to elect their chairman and vice chairman and representatives for the regional council.

\section{Why is it Necessary the Administrative-Territorial Reform}

Reforms of this nature are normal processes that take place in order to improve governance. After more than 20 years of changing political and economic system it is necessary to reflect on the outcome of democratization and in this context comes the need for the administrative-territorial reform.

Let mention some of the reasons most discussed and essential for this reform:

(i) we have high fragmentation of local government level, both as in terms of geographic fragmentation and in terms of representation of citizens;

(ii) since the last administrative- territorial organization of Albania, there have occurred major changes in

\footnotetext{
${ }^{4}$ Law no 8652, 31.07.2000

${ }^{5}$ Law no 8652
} 
demographic, socio-economic field but also regarding the representation in the territory and governance;

(iii) the efficiency in providing services to the citizens of municipalities and communes remains low;

(iv) the vast part of local government units fails to generate local economic development;

(v) There is high level of inequality between municipalities and communes in soci-economic background.

However, apart from these reasons there are a number of other elements that generate the need for reform and these are related to limited human resources, often facing the small local units. As a result, comes the inability to exercise the functions and generate local accumulated incomes or provide services. Also, another factor is the interrupted process of administrative and fiscal decentralization, somewhat from the low local human resources, but also from frequently and chaotic interventions in the legal basis, of the reduction of fiscal autonomy and non financial coverage from central government agencies of Common functions delegated to them. Another gap left since the 2000 law reform is the unclear role of the regions.

The administrative-territorial reform in the first level units, coupled with decentralization reform are designed to address and give a solution to this problem by creating bigger local units, not only in terms of the number of people they represent, but the human resources, local revenues, etc. Meanwhile, intermediate-level governance, or the second level governance unit such the region, is not intended to cover services such as water supply, building permits, street lighting, garbage collection, urban transport, which really need the residents to be near the center of service delivery. These services are and should remain at the level of municipalities. Region will cover functions that require larger scale, such as intercity transportation or management of protected natural areas, and where the interaction with citizens is of long duration. So the principle of subsidiarity is the key word in how the functions are allocated to each level of government.

\section{Conclusions/Results/Problems}

1. The system has been overflowing by many uneffective organs, that have result in non compliance with the citizens needs and objectives,

2. The system has been stuck by a large number of local gvernance units beyond any forecast, since Albanian territory is not as big enough to have such a large number,

3. There have been many costs just to pay the wages of officials, costs and funds that could have been used for a better propose, such as for new roads and parks for the citizens,

4. The new reform has cut the number of local government units and has change their organisation but the good implementation of it is yet to be prove.

\section{References}

"United cities and local governments", Gerard Marcou, Hellmut Wollman, www.uclg.org (publications)

"Local finance and affordable housing and the financial crisis", key issues for local government (same address supra note)

"The participation of human resources in Albanian local governance obligates", Zhyljen Papajorgji, Alba Dumi, Irma Gjika, Mediterranean Journal of Social Sciences, (vol.3, 3 September 2012, ISSN 2039-2117, Doi: 10.5901/mjss.2012.v3n3p409)

"Baltic experiences in Local Government", Larry A. Bakken

"Local Government in Latvia", Edvins Vanags, Paper presentation at 14 8-11, 1994)

"Comparing local government autonomy across states" Hal Wolman, Robert McManmon, Michael Bell, David Brunori, George Washington Institute of Public Policy, The George Washington University, www.gwu.edu/ gwipp

"Local government reforms in (Seven) European Countries: Between convergent and divergent, conflicting and complementary developments", Hellmut Wollmann, Humboldt University Berlin, Germany, (Local government studies, vol.38, No.1, 41-70, February 2012)

"L'esperienza di decentramento istituzionale in Italia e lo sviluppo locale", Daniela Adorni, Stefano Magagnoli (Relazione presentata agli incontri pratesi su lo sviluppo locale, Artimino, 12-16 settembre 2005, versione provvisoria)

"On the organization forms and structures of local government in European countries", Teki Kurti, Mediterranean Journal of Social Sciences, vo.4, no.9, October 2013, Doi: 10.5901/mjss.2013.v4n9p521)

"Italian Regions and local authorities within the framework of a new autonomist system" Gloria Marchetti, (Centro Studi sul Federalismo. Perspectives on Federalism. ISSN: 2036-5438)

Materials found in the Albanian State Central Archieve for the period 1920-1990

Organic law of local governance in Albania, Law no. 8652, dating 31.07 .2000 (with changes) 